\title{
Mapping and Damage Assessment of "Royal" Burial Mounds in the Siberian Valley of the Kings
}

\author{
Gino Caspari ${ }^{1,2}$ \\ 1 Department of Archaeology, University of Sydney, The Quadrangle A14, Sydney 2006, Australia; \\ gino.caspari@sydney.edu.au \\ 2 Institute of Archaeological Sciences, University of Bern, Mittelstrasse 43, 3012 Bern, Switzerland
}

Received: 4 February 2020; Accepted: 25 February 2020; Published: 28 February 2020

\begin{abstract}
The Valley of the Kings in Tuva Republic, southern Siberia, is arguably one of the most important archaeological landscapes in the eastern Eurasian steppes. Nonetheless, little information exists about the spatial characteristics and preservation conditions of this burial ground consisting of large "royal" mounds. We map the large monuments of the Uyuk Valley's northern river terrace and assess their state of preservation based on high-resolution optical satellite data. The burial site consists of several hundred mounds, over 150 of them with diameters of more than $25 \mathrm{~m}$, the largest monuments are bigger than $100 \mathrm{~m}$ in diameter. This makes the Valley of the Kings in Tuva Republic one of the largest Early Iron Age burial sites in the Eurasian steppes. Unfortunately, around $92 \%$ of the large monuments are in bad condition, mostly due to looting.
\end{abstract}

Keywords: burial mound; cultural heritage; looting; early iron age; Eurasian archaeology; Arzhan; satellite; remote sensing

\section{Introduction}

Due to a very high number of extremely large burial mounds in the Uyuk Valley, this remote region in the Sayano-Altai Mountains has acquired the vernacular name, "Valley of the Kings" (долина царей). The relative inaccessibility of the valley in the mountains of southern Siberia and the late inclusion of the Republic of Tuva in the Soviet Union in the 1940s led to a delayed start of the archaeological exploration of the region's Prehistory. When in the 1970s M. Gryaznov and M. Manaj-ool started to excavate a large and architecturally interesting burial mound from the Early Iron Age, the archaeological community was surprised. The burial mound revealed a then unique structure made from larch logs and a number of artifacts belonging to the "Scythian" cultural complex. Up until this point, the Siberian cultural branch of the Early Iron Age nomadic pastoralists had been considered an offshoot of the European Scythians. However, based on stylistic reasons, it was argued that this was one of the earliest appearances of the so-called "Scythian triad" consisting of weapons, horse gear, and objects in Scythian animal style dating to the late 9th/early 8th century BCE [1] (p. 72). This has since been scientifically confirmed by a number of radiocarbon dates [2]. Thus, first millennium horseback pastoralism was attributed to an emergence in the eastern Eurasian steppes, a hypothesis since supported by a number of studies, most recently [3]. The royal burial mound, Arzhan 1, and the archaeological landscape it was situated in thus became an important reference point for research on highly mobile nomadic pastoralists of the first millennium BCE. In 2001, a Russian German expedition uncovered an undisturbed royal tomb in the burial mound Arzhan 2 [4] (p. IX). To this date, it remains the richest burial of Early Iron Age nomadic pastoralists ever found, with several thousand gold items in a rarely seen quality of craftsmanship [5]. Arzhan 2, dating to the 7th century BCE [2], showed that the Uyuk Valley in Tuva Republic remained an important place for burials of the social elite during much of the first millennium BCE. In 2017, a Russian Swiss expedition surveyed and dated the large burial mound Tunnug 1 to the 
9th century BCE, finding another monument dating to the time of the Late Bronze Age-Early Iron Age transition in the eastern Eurasian steppes [6,7]. Research is currently on-going on three royal burial mounds in the Uyuk Valley, namely Chinge-tei 1 [8], Arzhan 5 [9], and Tunnug 1 [10].

Given these discoveries, the Valley of the Kings in southern Siberia can be considered among the most important archaeological landscapes for the study of "Scythian" material culture and the emergence of highly mobile nomadic pastoralism. However, the cultural heritage of the Eurasian steppes, in particular burial mounds, is under threat from looting [11] and other anthropogenic taphonomic processes, e.g., agricultural activity. Apart from a skeletal map published by Gryaznov in 1980 [12] (p. 4), few spatial data sets of this archaeological landscape have been generated and none are publicly available. In order to assess the extent of the "royal" necropolis in the Uyuk Valley, first and foremost accurate mapping of all large burial mounds is a desideratum. It is so far unclear how many large burial mounds exist on the northern terrace of the Uyuk River, how large these burial mounds are, what their spatial distribution is, and how they relate to each other.

This paper sets out to understand the spatial nature of large "royal" burial mounds in the Valley of the Kings in southern Siberia by (1) locating them using high-resolution satellite data, (2) analyzing their dimensions with regard to the dataset and to other burial sites of Early Iron Age pastoralists in the Eurasian steppe and (3) by assessing the mounds' states of preservation in order to make the first step towards the monitoring of an important cultural heritage.

\section{Materials and Methods}

Recent years have seen a rapid development in methods for archaeological remote sensing. Since mound-like archaeological features are a wide-spread and relatively homogenous phenomenon, archaeological landscapes with mounds are an ideal case for semi-automated and automated methods of classification and detection. Such methods were specifically applied with LiDAR-derived digital elevation models based on convolutional neural networks for identifying Neolithic mounds [13,14], and object-based approaches to find earthen mounds and shell heaps [15]. Other approaches used high-resolution optical satellite data, like Ikonos-2, and applied a random forests algorithm [16] or developed a training dataset for a neural network based on Google Earth images [17]. However, given the relatively small area of interest in the current study, it was decided to stick with a traditional visual interpretation. The number of large "royal" burial mounds in the Uyuk Valley, while large with respect to being a single archaeological site, is nonetheless small for generating a training dataset for more sophisticated machine learning approaches.

\subsection{The Area of Interest}

The area of interest is the northern river terrace alongside the Uyuk River in the Valley of the Kings in Tuva Republic (Figure 1). The valley lies in the northern part of Tuva Republic in the Sayan Mountains. The valley floor stays below $1000 \mathrm{~m}$ asl. The adjacent mountain ranges which define the valley go up to over $2000 \mathrm{~m}$ asl. Previous research into Early Iron Age burial mounds has shown that these archaeological structures are usually found on flat ground (cf. [18-20])—often river terraces like in the present case. Whereas small plateaus in between rocky areas and outcrops can display smaller mounds, this is not where monumental burials are usually found. These large burial mounds likely served a signaling function and thus were supposed to be seen [21]. They are likely to be located in areas where people passed through. Based on these findings, an elevation model from the Shuttle Radar Topographic Mission (SRTM) was employed to exclude all areas with a slope angle of more than $15^{\circ}$ from the search. To the south of the Uyuk River, the vegetation is dominated by shrubs, willows, and marshy areas. Only one large burial mound (Tunnug 1) is known from this particular area. The swamp is likely to contain smaller submerged monuments, but these are unlikely to be detected using optical data. As opposed to earlier studies [22], experiments with L-Band SAR have led to decent results in the detection of large stone based structures [6] but also show that, beyond the Early Iron Age burial mound Tunnug 1, there are no other monuments of similar size and composition 
in the vicinity. The search is therefore focused on the flat areas of the northern river terrace where steppe vegetation makes the mapping task straight forward.

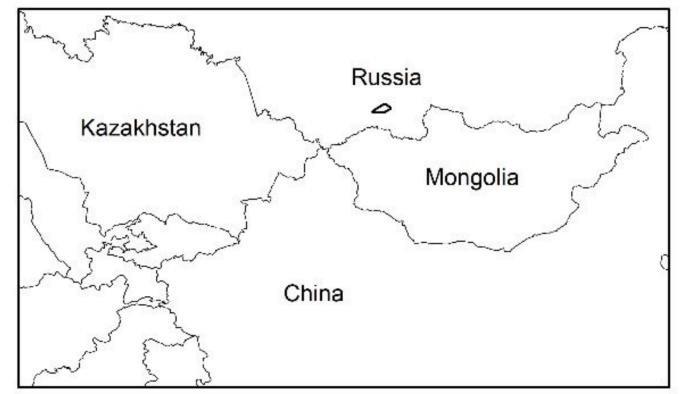

Area of Interest

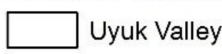

Elevation (SRTM)

m a.s.l.

High : 2900

Low : 350

Northern River Terrace

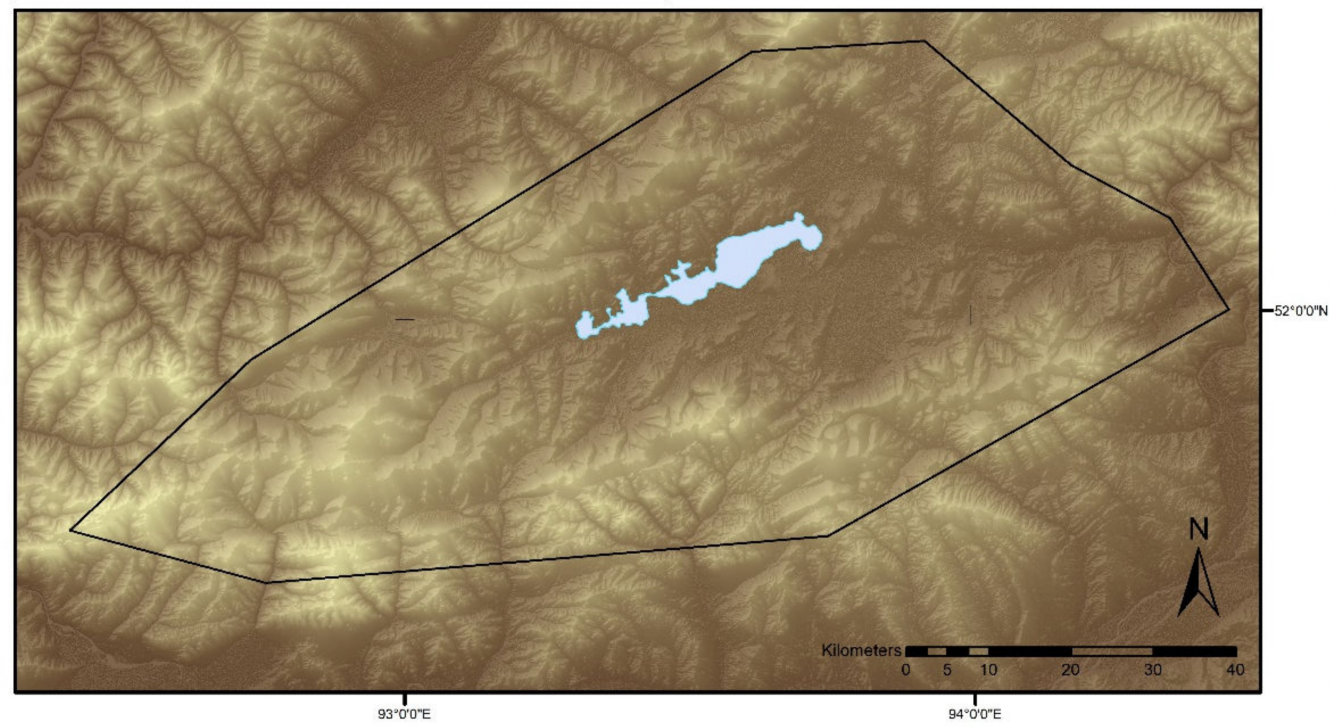

Figure 1. The area of interest in the Valley of the Kings in Tuva Republic, Russian Federation. The size of the area of interest on the northern river terrace measures $100 \mathrm{~km}^{2}$.

\subsection{Mapping the "Royal"Burial Mounds and Assessing Their Preservation Conditions}

The European Space Agency supplied $200 \mathrm{~km}^{2}$ panchromatic WorldView-2 data dating back to September 12th, 2009. These data have a resolution of up to $0.46 \mathrm{~m}$ at nadir for this band. Early September is a time when there is yet to be precipitation in the form of snow, potentially making the search for mounds more difficult. At the same time, the growth intensity of the vegetation is already decreasing and some of the local residents start cutting and drying grass as fodder for the livestock in winter. This can increase visibility of archaeological features like mounds. A search grid with $500 \times 500 \mathrm{~m}$ cells was created over the high-resolution satellite data. Each square was then searched for mounds. All recognizable mounds, independent of size, were mapped and marked with a circle defining their approximate extent.

Consistent with the approach tested in [11], the preservation conditions of small burial mounds are difficult to assess due to the limited number of pixels through which they are represented. For larger burial mounds, a binary classification into the two categories [impacted/well-preserved] is fairly reliable. All burial mounds larger than $23.4 \mathrm{~m}$ in diameter (mounds which are in the fourth quartile of the diameter distribution) were analyzed and assigned to one of these two categories. Figure 2 shows examples of large burial mounds for both categories. Note that a categorization of a monument as [well-preserved] does not necessarily mean it is untouched. It merely indicates that no traces of direct destruction can be seen in the WorldView-2 data. 

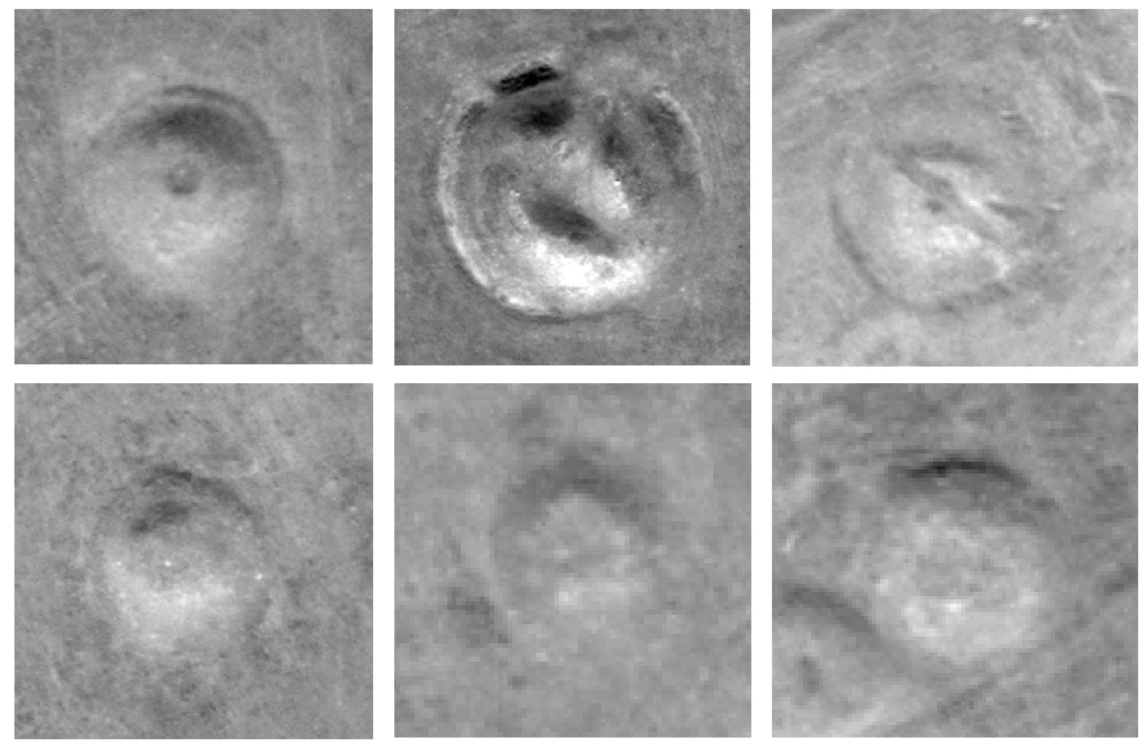

Figure 2. The top row shows "royal" burial mounds which are heavily impacted by looting and thus were attributed to the [impacted] category. The bottom row shows mounds which seem to be well-preserved and are thus attributed to the [well-preserved] category. The bottom right image shows two burial mounds of which only the middle one seems to be well-preserved. All images are scaled to the same size for comparability purposes.

\section{Results}

In total, 716 burial mounds were found based on the WorldView-2 data within the borders of the area of interest. Since all recognizable mounds and not only very large burial mounds were mapped, there is a substantial portion of smaller mounds between around $5 \mathrm{~m}$ and $20 \mathrm{~m}$ which do not necessarily date to the Early Iron Age and might have served other purposes than burial (Figure 3). It also cannot be assumed that all of these small archaeological features were found. The complete set of data is thus heterogeneous for the smaller monuments. The smaller mound structures merely represent a selection of highly visible monuments mostly in the vicinity of larger burial mounds. Since most large burial mounds do have a periphery of smaller stone monuments [6], circular features in the immediate vicinity of a large burial mound are contextualized and thus more easily recognizable as archaeological structures.

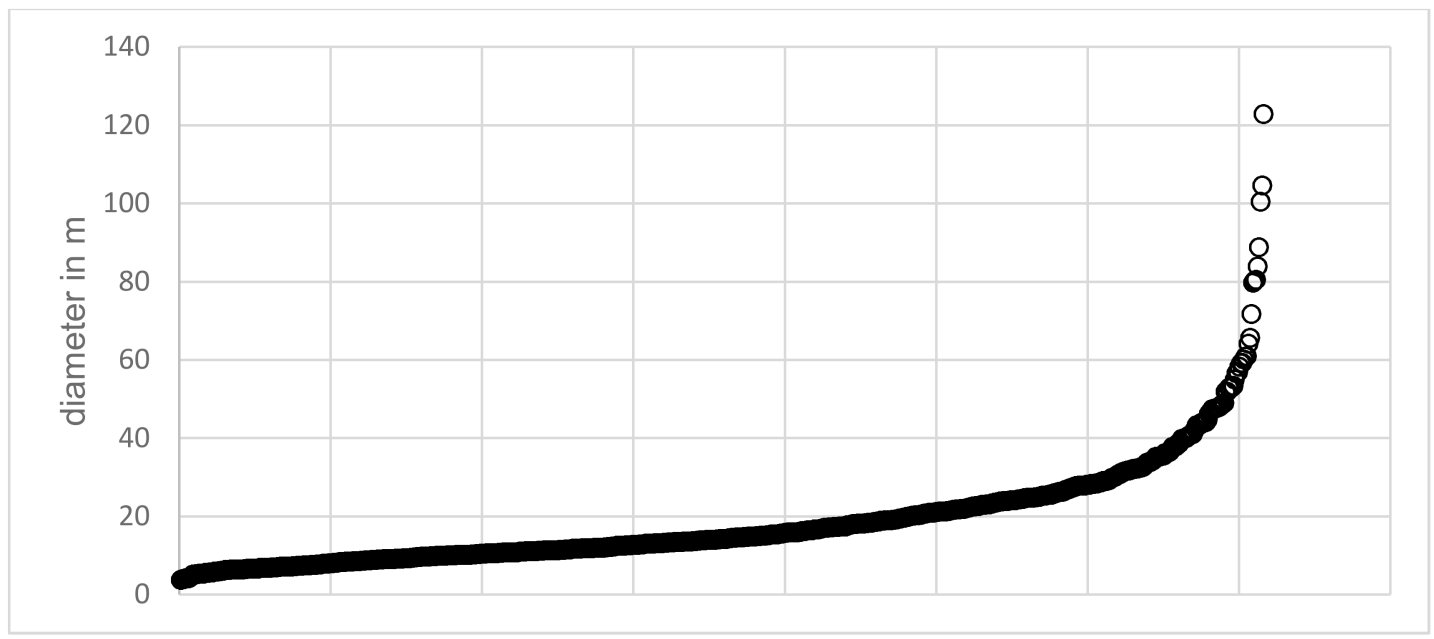

Figure 3. Mapped burial mounds ordered based on diameter. 
With a median of $14.2 \mathrm{~m}$, most of the burial mounds are small- or middle-sized mounds. The smallest mapped mound has a diameter of $4 \mathrm{~m}$; the largest mound has a diameter of $123 \mathrm{~m}$. These measurements are not very accurate but are meant to give an approximation of the actual size of these monuments. Arzhan 1 was considered having a diameter of $120 \mathrm{~m}$ by the excavators [12] (p. 5), whereas an approximate diameter of $123 \mathrm{~m}$ was measured based on the WorldView-2 data. Arzhan 1 is also a difficult case since the entire monument has been removed and only traces remain. The distribution of diameters has no outliers at the lower end. However, there are a number of outliers at the upper end which stand for extremely large monuments. The interquartile range multiplied by 1.5 is used to identify the outliers. There are 44 outliers, i.e., monuments which are larger than $43.4 \mathrm{~m}$ in diameter (Figure 4 ). We consider all mounds in the fourth quartile ( $23.4 \mathrm{~m}$ in diameter and larger) and all outliers to be of interest for further investigation concerning their state of preservation.

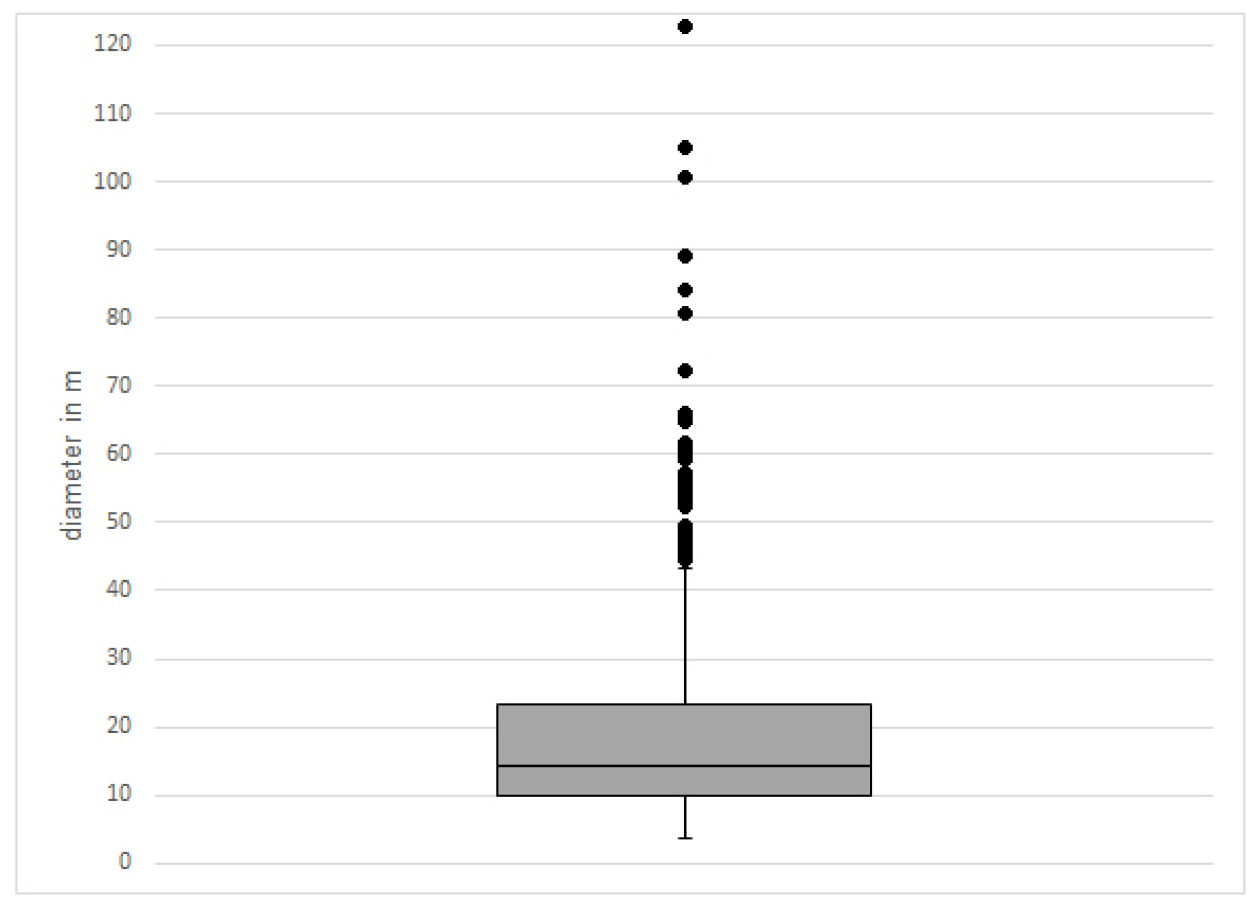

Figure 4. Box plot of mound diameter distribution excluding outliers (interquartile range $\times 1.5$ ). Median: 14.2 m; Q1: 10.0 m; Q3: 23.4; Min: 3.8 m; Max (excluding outliers): 43.4 m.

Out of 716 initially mapped mounds, the 178 (Q4 + outliers) with the largest diameters were visually assessed for damage. The obvious signs of looting are deep holes in the center of the burial mound. Mounds which were ploughed end up having an irregular, often elongated shape and a fuzzy border. Out of 178 assessed monuments, only 14 seemed to be well-preserved. All others were clearly impacted by destructive anthropogenic activities. Note that burial mounds which were the target of excavations also fall into the [impacted] category. Archaeologists in the area usually do not expect burials to be unlooted. The only case where an undisturbed burial was found-Arzhan 2-was due to an off-center burial chamber and a decoy chamber which distracted looters [4]. In total, 92\% of all mapped large burial mounds seem to have been impacted; many are heavily disturbed.

\section{Discussion}

With more than 700 mound structures on the northern river terrace, the Valley of the Kings seems to carry its name for a reason, although the term "kings" certainly needs to be specified. Around 150 of them have a diameter of more than $25 \mathrm{~m}$, which hints towards considerable human labor going into their construction. Likely all of these monuments date to the Early Iron Age, given that so far 
no archaeological evidence has been discovered which would assign any of the large monuments to another chronological period. This accumulation of monuments thus stands for an extraordinary cultural tradition, extending over several centuries, which has clear implications for the social structure and organization of highly mobile nomadic pastoralists of the first millennium BCE. Most burial mounds are organized in chains in the direction of the valley (Figure 5). The alignment in chains is known from other Early Iron Age burial sites in the Altai, Eastern Kazakhstan, and Northern Xinjiang. Sometimes, these alignments are interpreted as being associated with family ties of the buried individuals, but this remains to be proven [20]. In this case a dynastic connection between the individuals interred in the burial mound rows would be an alternative although not necessarily conflicting hypothesis.

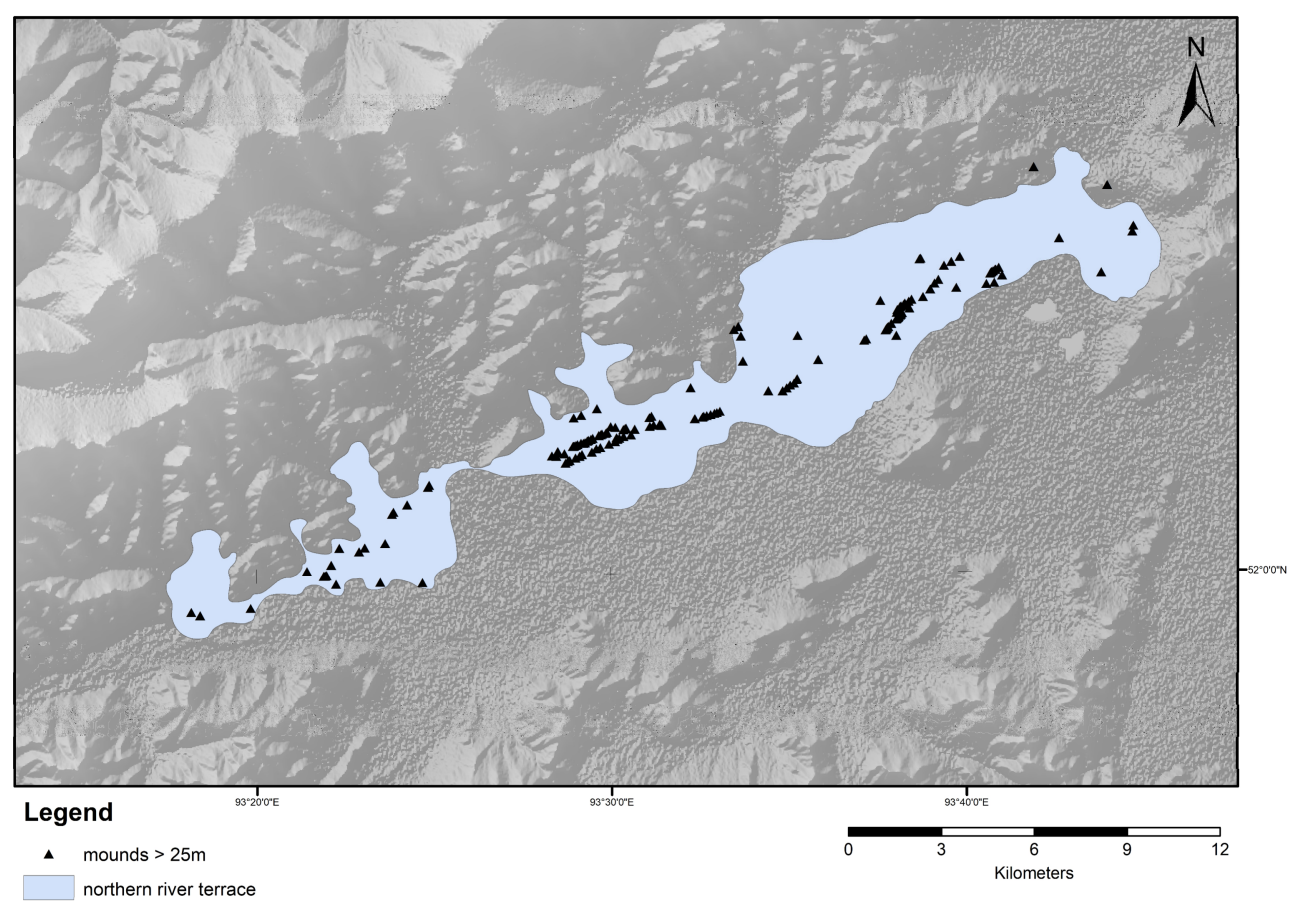

Figure 5. Northern river terrace in the Valley of the Kings with mapped mounds over $25 \mathrm{~m}$ in diameter. Several long chains of large burial mounds can be recognized.

There is a large number of Early Iron Age burial grounds throughout the Eurasian steppes associated with the "Scythian" material culture complex. In eastern Eurasia, several archaeological subcultures, like the Saka in Eastern Kazakhstan, the Pazyryk culture in the Altai Mountains, and the Tagar culture in the Minusinsk Basin, are distinguished archaeologically. In all these areas, the larger mounds have been called "royal" or "princely" tombs, but often it remains unclear what this designation actually means. In Russian literature, the word "ца́рский" is used to describe burials of the highest social stratum. All these terms are usually used to either characterize very large burial mounds in an intra-site frame of reference or in order to suggest that a specific site was a focal point for funerary ritual activity beyond the immediate geographical context. Exemplarily, we can compare some of the well-known "royal" burial sites of Early Iron Age nomadic pastoralists to the diameter distributions generated here. The Issyk burial ground consists of 52 large burial mounds between 16 and $145 \mathrm{~m}$ in diameter [23]. These measurements likely include peripheral structures like ditches, stone rings, and "ritual roads" and are therefore not directly comparable. The largest mound at Issyk without its periphery has a diameter of around $115 \mathrm{~m}$ based on a measurement in Google Earth. The Turgen burial ground consists of roughly 30 middle and large sized mounds between 22 and $70 \mathrm{~m}$ in diameter [23]. The Asy Zaga burial ground consists of only six but has very large mound features ranging from 40 
to $148 \mathrm{~m}$ [23]. In the Altai Mountains, the largest mound structures within a site tend to be smaller, even for sites which are designated with the term "royal." The largest mounds of the Berel' site which are often called "princely" tombs reach diameters between 30 and $40 \mathrm{~m}$ [24,25]. The large mounds at the "royal" burial ground Pazyryk reach sizes between 40 and $50 \mathrm{~m}[25,26]$. With over 150 burial mounds over $25 \mathrm{~m}$ in diameter, more than 50 over $40 \mathrm{~m}$ in diameter and a few of the largest monuments reaching diameters of over $100 \mathrm{~m}$, the Valley of the Kings in Tuva Republic is clearly one of the most impressive Early Iron Age sites in the Eurasian steppes (Figure 6).

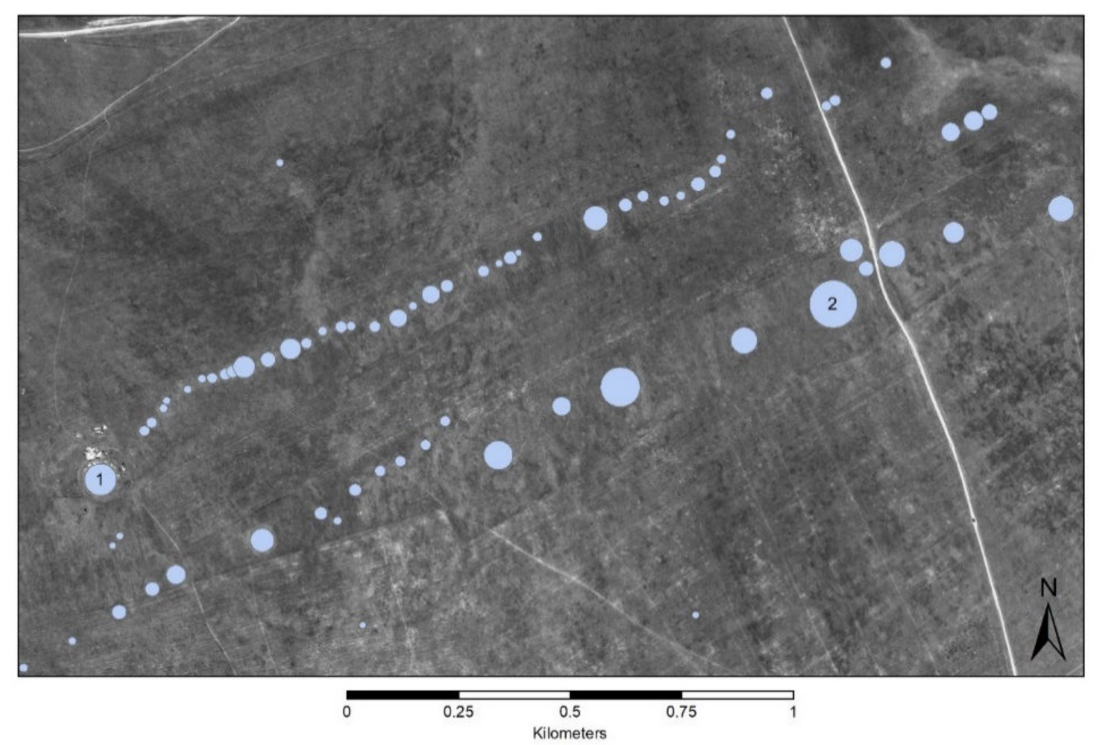

Figure 6. Several longer lines of burial mounds (all shown mounds $>15 \mathrm{~m}$ ) with the Chinge-tei 1 burial mound currently under excavation (1) and another "royal" tomb, over $100 \mathrm{~m}$ in diameter, which was heavily disturbed (2).

The statistical analysis of the diameter distribution yields a large number of outliers towards the upper end (Figure 4). A small number of rather flat but extremely large monuments set themselves apart with diameters of over $70 \mathrm{~m}$. These are the excavated burial mounds Arzhan $1(120 \mathrm{~m})$ and Arzhan $2(80 \mathrm{~m})$ as well as Chinge-tei 1 (>100 $\mathrm{m}$ including the moat) currently under scientific investigation. The burials Arzhan $3(90 \mathrm{~m})$ and Arzhan 4 (>100 m) also belong in this category. Additionally, the burial mound Tunnug 1 in the south of the valley has been shown to be of similar size ( $>100 \mathrm{~m})$ and have similar architectural features to Arzhan 1 [6]. The burial mounds Arzhan 1-4 line up approximately in the direction of the valley over a distance of more than $8 \mathrm{~km}$. A shapefile with all burial mounds with a diameter of $>20 \mathrm{~m}$ can be found in Supplementary Materials.

The preservation circumstances of the Early Iron Age mound-scape in the Valley of the Kings in Tuva is rather dire. A mere $8 \%$ of large burial mounds are potentially in good condition. As a previous study with complete groundtruth by the author showed, remote sensing-based assessment of looting related damage of burial mounds is delivering a good approximation for the circumstances at mound sites in a steppe environment [11]. This fact allows for continuous monitoring of a site. Similar attempts to monitor and quantify looting are now being employed worldwide (e.g., [27-30]). The Valley of the Kings in Tuva Republic has been known for its large burial mounds for a long time. Most severe destructions are not of a very recent date. In the 17th and 18th century with the exploration of Siberia by the Russian Empire, a veritable gold rush led to the destruction of countless burial mounds in the Eurasian steppes, but also to the dawn of "Scythian" archaeology [31]. Since then, looting in the Valley of the Kings seems to have slowed down. Archaeological research activity in the Uyuk Valley is relatively high and new looting is likely to be detected quickly. Additionally, many local residents are aware of the value of this cultural landscape and their past and are thus protective of their cultural 
heritage. However, it is concerning how much damage has already been inflicted upon a uniquely important site (Figure 7).
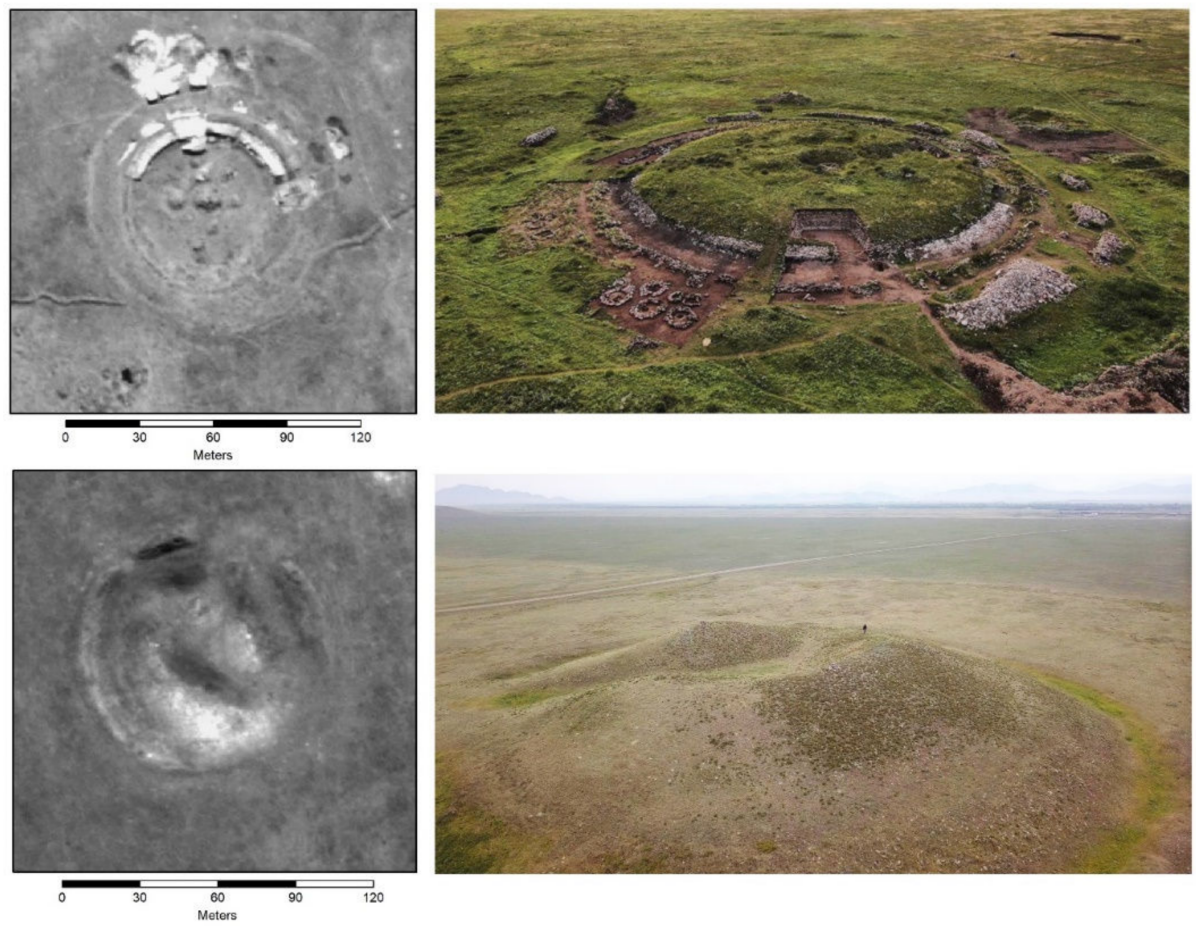

Figure 7. The two large "royal" burial mounds marked in Figure 6 are both heavily impacted by looting. Top (1): despite large looting pits in the center of the stone mound, the archaeological investigation is yielding results, undisturbed peripheral burials have been found at Chinge-tei 1. Bottom (2): The center of this "royal" tomb has been completely destroyed by looters. The small person in black gives a sense of the size of these monuments (Photographs by T. Wallace).

\section{Conclusions}

The Valley of the Kings in Tuva Republic, Russian Federation, is a unique site for the study of Early Iron Age nomadic pastoralists. Mapping all visible mound features in WorldView-2 panchromatic data, it becomes clear that the northern river terrace of the Uyuk River was the location for an immense construction effort of funerary ritual monuments during the first millennium BCE. It is one of the richest sites in terms of the quantity of burial mounds and the size of individual monuments in the Eurasian steppes, and therefore deserves appropriate attention in terms of cultural heritage protection. Unfortunately, almost all "royal" mounds (92\%) have been impacted by severe looting activity and/or agriculturally expedited taphonomics. What is left needs to be protected, starting with a regular monitoring effort.

Supplementary Materials: The following are available online at http://www.mdpi.com/2072-4292/12/5/773/s1. Shapefile with burial mounds $>20 \mathrm{~m}$. Without indications of preservation conditions.

Funding: This research was funded by the Swiss National Science Foundation, grant number P400PG_190982. The European Space Agency supplied high-resolution satellite data under the Project Start-Up id. 54058.

Conflicts of Interest: The author declares no conflict of interest.

\section{References}

1. Simpson, S.J.; Pankova, S. (Eds.) The BP Exhibition: Scythians: Warriors of Ancient Siberia; Thames \& Hudson: London, UK, 2017. 
2. Zaitseva, G.I.; Chugunov, K.V.; Alekseev, A.Y.; Dergachev, V.A.; Vasiliev, S.S.; Sementsov, A.A.; Cook, G.; Scott, E.M.; van Der Plicht, J.; Parzinger, H.; et al. Chronology of key barrows belonging to different stages of the Scythian period in Tuva (Arzhan-1 and Arzhan-2 barrows). Radiocarbon 2007, 49, 645-658. [CrossRef]

3. Taylor, W.T.; Clark, J.; Bayarsaikhan, J.; Tuvshinjargal, T.; Jobe, J.T.; Fitzhugh, W.; Kortum, R.; Spengler, R.N.; Shnaider, S.; Seersholm, F.V.; et al. Early Pastoral Economies and Herding Transitions in Eastern Eurasia. Sci. Rep. 2020, 10, 1-15. [CrossRef] [PubMed]

4. Chugunov, K.; Parzinger, H.; Nagler, A. Der Skythenzeitliche Fürstenkurgan Aržan 2 in Tuva: Archäologie in Eurasien 26, Steppenvölker Eurasiens 3; Philipp von Zabern: Mainz, Germany, 2010.

5. Armbruster, B. Gold Technology of the Ancient Scythians-Gold from the Kurgan Arzhan 2, Tuva. ArcheoSci. Rev. D'archéométrie 2009, 31, 187-193. [CrossRef]

6. Caspari, G.; Sadykov, T.; Blochin, J.; Buess, M.; Nieberle, M.; Balz, T. Integrating Remote Sensing and Geophysics for Exploring Early Nomadic Funerary Architecture in the "Siberian Valley of the Kings". Sensors 2019, 19, 3074. [CrossRef]

7. Caspari, G.; Sadykov, T.; Blochin, J.; Hajdas, I. Tunnug 1 (Arzhan 0)—An Early Scythian Kurgan in Tuva Republic, Russia. Archaeol. Res. Asia 2018, 15, 82-87. [CrossRef]

8. Chugunov, K. The discontinuity of construction of the "royal" memorials of Tuva and the chronology of the Early Scythian time. In Terra Scythica (In Russ. Чугунов К.B. ДискретностьПостройки“Царских” Мемориалов Тувы и Хронология Раннескифского Времени); Izdatel'stvo Instituta archeologii i ètnografii SO RAN: Novosibirsk, Russia, 2011; pp. 358-369.

9. Rukavishnikova, I.; Gladchenkov, A. Studies of Arzhan-5 in the Turan-Uyuk Basin//KSIA, Iss. (In Russ. Рукавишникова И.В., ГладченковА.А. ИсследованияАржана-5 в Турано-Уюкской котловине//КСИА, Вып. Quat. Int. 2018, 469, 30-43.

10. Caspari, G.; Sadykov, T.; Blochin, J.; Bolliger, M.; Szidat, S. New Evidence for a Bronze Age Date of Chariot Depictions in the Eurasian Steppes. Rock Art Res. 2020, 37, 1-6.

11. Caspari, G. Assessing Looting from Space: The Destruction of Early Iron Age Burials in Northern Xinjiang. Heritage 2018, 1, 320-327. [CrossRef]

12. Gryaznov, M.P. Arzhan: Tsarskii Kurgan Ranneskifskogo Vremeni (Arzhan: A Royal Barrow of Early Scythian Time); Nauka: Leningrad, Russia, 1980.

13. Guyot, A.; Hubert-Moy, L.; Lorho, T. Detecting Neolithic burial mounds from LiDAR-derived elevation data using a multi-scale approach and machine learning techniques. Remote Sens. 2018, 10, 225. [CrossRef]

14. Lambers, K.; Verschoof-van der Vaart, W.B.; Bourgeois, Q.P. Integrating remote sensing, machine learning, and citizen science in Dutch archaeological prospection. Remote Sens. 2019, 11, 794. [CrossRef]

15. Davis, D.S.; Sanger, M.C.; Lipo, C.P. Automated mound detection using LiDAR and object-based image analysis in Beaufort County, South Carolina. Southeast. Archaeol. 2019, 38, 23-37. [CrossRef]

16. Caspari, G.; Balz, T.; Gang, L.; Wang, X.; Liao, M. Application of Hough Forests for the detection of grave mounds in high-resolution satellite imagery. In Proceedings of the 2014 IEEE Geoscience and Remote Sensing Symposium, Quebec City, QC, Canada, 13-18 July 2014; pp. 906-909.

17. Caspari, G.; Crespo, P. Convolutional neural networks for archaeological site detection-Finding "princely" tombs. J. Archaeol. Sci. 2019, 110, 104998. [CrossRef]

18. Gass, A. Das Siebenstromland Zwischen Bronze-Und Früheisenzeit: Eine Regionalstudie; Walter de Gruyter GmbH \& Co KG: Berlin, Germany, 2016; Volume 28.

19. Bourgeois, J.; Cheremisin, D.V.; Plets, G.; Dvornikov, E.P.; Ebel, A.V.; Stichelbaut, B.; van Hoof, L.; Gheyle, W. An archaeological landscape in the Dzhazator Valley (Altai Mountains): Surface monuments and petroglyphs from the chalcolithic to the ethnographic period. Archaeol. Ethnol. Anthropol. Eurasia 2014, 42, 106-119. [CrossRef]

20. Caspari, G. Quantifying the Funerary Ritual Activity of the Late Prehistoric Southern Kanas Region (Xinjiang, China). Asian Perspect. 2020, 59, 2, (Forthcoming).

21. Wright, J. The honest labour of stone mounds: Monuments of Bronze and Iron Age Mongolia as costly signals. World Archaeol. 2017, 49, 547-567. [CrossRef]

22. Balz, T.; Caspari, G.; Fu, B.; Liao, M. Discernibility of burial mounds in high-resolution X-Band SAR images for archaeological prospections in the Altai Mountains. Remote Sens. 2016, 8, 817. [CrossRef]

23. Gass, A. Early Iron Age burials in southeastern Zhetysu: The geoarchaeological evidence. Archaeol. Ethnol. Anthropol. Eurasia 2011, 39, 57-69. [CrossRef] 
24. Gheyle, W. Highlands and Steppes: An Analysis of the Changing Archaeological Landscape of the Altay Mountains from the Eneolithic to the Ethnographic Period. Ph.D. Thesis, Ghent University, Ghent, Belgium, 2009.

25. Ochir-Goryaeva, M. The Peculiarities of the Geographical Distribution of the Pazyryk Kurgans. Anc. Civiliz. Scythia Sib. 2017, 23, 329-354. [CrossRef]

26. Hiebert, F.T. Pazyryk chronology and early horse nomads reconsidered. Bull. Asia Inst. 1992, 6, 117-129.

27. Agapiou, A.; Lysandrou, V.; Hadjimitsis, D.G. Optical remote sensing potentials for looting detection. Geosciences 2017, 7, 98. [CrossRef]

28. Tapete, D.; Cigna, F. Detection of Archaeological Looting from Space: Methods, Achievements and Challenges. Remote Sens. 2019, 11, 2389. [CrossRef]

29. Lasaponara, R.; Danese, M.; Masini, N. Satellite-based monitoring of archaeological looting in Peru. In Satellite Remote Sensing; Springer: Dordrecht, The Netherlands, 2012; pp. 177-193.

30. Lasaponara, R.; Masini, N. Combating illegal excavations in Cahuachi: Ancient problems and modern technologies. In The Ancient Nasca World; Springer: Cham, Switzerland, 2016; pp. 605-633.

31. Korolkova, E. The Siberian Collection of Peter the Great. In The BP Exhibition: Scythians: Warriors of Ancient Siberia; Simpson, S.J., Pankova, S., Eds.; Thames \& Hudson: London, UK, 2017.

(C) 2020 by the author. Licensee MDPI, Basel, Switzerland. This article is an open access article distributed under the terms and conditions of the Creative Commons Attribution (CC BY) license (http://creativecommons.org/licenses/by/4.0/). 